\title{
Contact, attitude, and motivation in the learning of Catalan at advanced
}

\section{levels}

Colleen Hamilton ${ }^{1}$

Departament de Filologia Anglesa i Alemanya, Universitat de Barcelona

Email: crhamilton2@wisc.edu Phone:1.616.516.9038

Raquel Serrano

Departament de Filologia Anglesa i Alemanya, Universitat de Barcelona

Gran Via de les Corts Catalanes, 585, 08007 Spain

Email: raquelserrano@ub.edu Phone:0034.93.403.5679

\begin{abstract}
The theoretical complexity of current understandings of second language (L2) identity has brought the study of language learning motivations from basic concepts of intrinsic, integrative, and instrumental motives to a more dynamic construct that interacts with background factors, learning contexts, and proficiency levels. This cross-sectional study examines the profile of the advanced non-native learner of Catalan as a means of understanding L2 contact, attitudes, and motivations that underlie the self-concept of this learner group as distinct from foreign language learners. Adult students in advanced courses $(N=90)$ in Catalonia responded to questionnaire items about the presence of the target language in their social network, attitude toward it, motivation for studying, and background information including age and length of residence, among others. Principle component analysis revealed four driving factors for language study, which are discussed in terms of learners' Ideal and Ought-to L2 Selves from the L2 Motivation Self System (Dörnyei, 2009), in addition to mediating L2 community factors found uniquely in second language study contexts. Through discussing these motivations, we hope to arrive at a better understanding of learners who, arriving in a multilingual community, form an advanced L2 self-concept and translate these push and pull factors into proficiency.
\end{abstract}

Keywords: community language, language contact, language attitudes, L2 Motivational Self System, integrative motivation, multilingualism

\footnotetext{
${ }^{1}$ Corresponding author. Current affiliation: Program in Second Language Acquisition, University of
} Wisconsin-Madison, 1322 Van Hise Hall, 1220 Linden Drive, Madison, Wisconsin, 53706 USA. 


\section{Introduction}

The varied modalities of second language (L2) acquisition present a rich field for research on L2 learner identity. In this study, we investigate the attitudes and motivations of advanced learners of Catalan in multilingual Catalonia where learners and native speakers intermix. This sociolinguistic reality creates a simultaneous immersion experience in both Catalan and Spanish, with access to other international languages, distinguishing these L2 Catalan learners from foreign language (FL), and particularly English as a Foreign Language (EFL) learners. Participants pursue advanced proficiency in a language that does not advertise largescale economic or social benefits and that may be obscured by other global languages, particularly Spanish and English. Given this setting, what do Catalan learner motivations reveal about learners' self-concept? This research provides additional insight into L2 self theory (Dörnyei, 2009) by examining possible Ideal and Ought-to L2 selves within a multilingual context.

Using cross-sectional survey research, this study documents three constructs: contact, the interaction between learners and L2 settings and speakers; attitude, learners' dispositions toward the L2; and motivation, the overlapping and evolving reasons learners give for their study of the L2. It examines these three constructs in the study of Catalan at the advanced level, their interaction, and differences across learner populations. The target population of the current study is non-native speakers, defined as those whose first language (L1) is not Catalan and who immigrated to Catalonia after the age of ten.

Some historical information about Catalonia is necessary to contextualize this learner population. In 1978, Catalonia became an autonomous community within Spain, with both Catalan and Spanish as official languages. Educational linguistic policy then reinforced a Catalan immersion educational system where proficiency in both Catalan and Spanish is a mandatory outcome. Additionally, the Consortium for Linguistic Normalization (Consorci 
per a la Normalització Lingüística or CPNL) is the main Catalan body responsible for extracurricular Catalan courses, serving 98,300 students (CPNL, 2012). Adults having completed compulsory schooling before 1988 received most formal instruction in Spanish, which explains the portion of advanced Catalan students at the CPNL who are in fact native speakers of the language. Extensive immigration of native Spanish speakers, internally from Spain in the 1960s and 70s and externally from Latin America in the $21^{\text {st }}$ century has resulted in a significant population of native Spanish-speaking children in schools in Catalonia (Moraga \& Ferer-i-Carbonell, 2008). Because of Catalonia's bilingualism, Spanish speakers do not face a language barrier; yet they are the overwhelming majority of advanced Catalan language students, reaching $80 \%$ in this study. The motivation to acquire an additional shared language, at the highest proficiency level, in the second language context, further distinguishes these students from FL learners.

Specifically, this research explores the self-concept of non-Catalans who enroll in advanced Catalan language classes, thereby extending the scope of research on learner motivation to include multilingual contexts. This investigation seeks to understand the full complexity of the environmental, attitudinal, and motivational factors driving these learners.

\section{Literature Review}

\section{Contact}

This factor both creates and is influenced by the L2 learner's environment. Aspects of L2 contact have been synthesized in the Language Contact Profile created by Freed, Dewey, Segalowitz, and Halter (2004) to measure target language use in study abroad contexts. The instrument can be expanded by notions of Social Network Analysis, which sheds light on people-specific interaction (Daming, Xiaomei, \& Wei, 2008; Milroy, 1980, 2000). This 
analysis examines an individual's regular interlocutors as a network with the capacity to enforce language norms (Milroy, 2000). A social network which is more oriented toward the L2 community and allows for higher frequency of input and output fosters greater L2 proficiency (Raschka, Wei, \& Lee, 2002; Wiklund, 2002), and this link may stem from positive attitudes and motivations engendered by L2 contact. The learner's links to family, friends, and colleagues encompass first-order ties in the learner's social network, and the group's language practices reinforce the status of the respective languages and may determine language attitudes and motivations.

A case study of two immigrant students in Catalonia conducted by Cots and Nussbaum (2008) highlights the weight of language contact and its influence on language learning. For new arrivals to the Catalan immersion education system, the school represents a gate-keeping institution that socializes students through language classes. The study found that learning Catalan represents not only a gain in communicative ability: proficiency also carries social capital, underlies identity construction, represents a process of socialization, and signifies an investment in a new language and culture. The learner's pursuit of advanced L2 proficiency can best be interpreted in terms of the participant's surroundings and relationships.

Moreover, Newcombe and Newcombe (2001) found contact with the target L2 to be crucial in language study perseverance in multilingual contexts. In their study of adult Welsh learners, anticipation of opportunities to practice correlated with course completion, and actual opportunities to practice - complemented by support from native Welsh speakerscorrelated with use of the target language several months after course completion. To summarize, learners continue to study and use the language because of meaningful relationships based in the target language, a measure of the strength of social networks and an inherent piece of L2 learners' self-concept. 


\section{Attitude}

Attitudes interact with feelings of integrativeness (Gardner, 2000, 2010), or L2 learners' desire to use the language to affiliate themselves with the L2 community. This orientation, consisting of positive attitudes toward the L2 community and high motivation for language learning, leads to high levels of L2 proficiency (Dörnyei, 2003, 2005). If attitudes evolve through interactions with L2 speakers, and the resulting L2 network reinforces positive attitudes and other community identifiers and norms, then language attitudes play an integral role in the emergence of L2 self-concept. Indeed, the expanded use of Welsh by advanced Welsh learners prompted increasingly positive attitudes toward the target language and its use in daily life (Coupland, Bishop, Williams, Evans, \& Garrett, 2005).

Research conducted in Catalonia shows that attitudes toward Catalan can be taken as a measure of community use, perceived usefulness, and integration (Bernaus, Masgoret, Gardner, \& Reyes, 2004; Gore, 2002; Trenchs-Parera \& Newman, 2009). In a study by Huguet and Janés (2008; see also Huguet \& Llurda, 2001) where immigrant learners responded to normative language evaluations, fewer demonstrated favorable attitudes toward Catalan (65\%) than Spanish (71\%). Variance was attributable to native language, where Spanish-speakers from Latin America scored significantly lower regarding Catalan than other groups, and these negative attitudes correlated with low L2 proficiency. This native language bias in multilingual contexts speaks to the interplay of social network, positive attitudes, and motivation that favor voluntary L2 study and constitute learners' self-concept.

\section{Motivation}

Motivation to learn has proven even more important to L2 achievement than language attitudes (Masgoret \& Gardner, 2003). Current L2 motivation theory centers on the self- 
concept of learners, or how they imagine possible future versions of themselves (Dörnyei \& Ushioda, 2009; Ushioda, 2011). Citing research at the confluence of personality and motivational psychology, Dörnyei's (2009) L2 Motivational Self System has integrated the theory of possible selves (Higgins, 1987) with research on L2 motivation, where motivation and achievement are connected by the learner's image of a successful future self. In this system, the Ideal L2 is the best case scenario, while the Ought-to L2 self represents traits to avoid or norms to obey. The combination of push and pull factors, or the discrepancy between the current and Ideal/Ought-to L2 selves, provides the motivation for action. The learner's clear self-concept image activates the step-by-step goals necessary for achieving the long-term Ideal L2 self.

The L2 Motivational Self System has grown out of previous theoretical frameworks such as the Socio-Educational Model (Gardner, 2010). According to the model, integrativeness consists of the learner's positive orientation toward the L2 community and fosters positive attitudes and greater motivation, leading to increased L2 achievement (Gardner, 2001). Integrativeness as a measure of identification with the L2 community is where identity, or how learners conceptualize themselves, is most clearly implicated in language learning. Of importance in the present study is the multilingual context, where contact with speakers of the L2, integrativeness, and attitude are the elemental components of motivational self-concept.

Self-Determination Theory also contributes to research on L2 motivation by putting forth an expanded model of intrinsic and extrinsic reasons for language learning (Deci \& Ryan, 1985; Noels, Pelletier, Clément, \& Vallerand, 2000). The continuum of internalization posits that learners take on external contingencies of their environment (Noels, 2001a). Therefore, analyzing My job requires it and It can be useful at work as a single motive is no longer meaningful. While the former is an obligation, the latter is a recognition of usefulness 
on the part of the learner, who then exerts effort to realize possible benefits. Intrinsic motivations sourced from the learner's own interest or desire to succeed are more selfdetermined than extrinsic motivations. Evidence links intrinsic motivation with increased language use and positive attitudes (Noels, 2001b), and moreover, learners in immersion settings scored higher on a measure of extrinsic motivation linked with strong L2 identity affiliation (Goldberg \& Noels, 2006). Self-determined motivations for language learning are thus conceptually related to vivid learner self-concept. The motivational scales used in the present study are framed by Self-Determination Theory, including a scale referring to external motivating factors that the learner has completely integrated into his self-concept. Noels notes that few studies have been conducted with learners who are advanced enough to have integrated the L2 into their self-concept (2001b). This scale provides the theoretical link between previous models of L2 motivation and images of the L2 Self.

The new direction of motivation studies reflects the evolving complexity and modalities of interaction with an L2 community and the possible selves learners can draw from this. Arguably, the concept of a target L2 community for English may have become less useful as the language has spread, diversified, and become more accessible (Dörnyei, 2009). However, we argue here that the concept remains informative and appropriate in multilingual contexts such as Catalonia, where the L2 community is close at hand and may prove essential to the construction of the L2 self-concept of immigrants to the region.

An initial insight into self-concept in this context is offered by Bernadó, Comajoan, and Bastons (2008). The researchers found that the primary motivating factor for beginning learners of Catalan is general intrinsic motivation, and additional significant factors include work, linguistic anxiety, integrativeness, social reinforcement, and studies. These findings on beginning L2 learners identify the research gap to be filled in the study of L2 learner 
motivation. A study of advanced adult Catalan learners is needed to explore learner selfconcept, investigate the relevance of integrativeness for highly proficient learners in noncompulsory settings, and take into account additional factors such as contact with the L2. Furthermore, many new ideas have surfaced related to the L2 Self but have focused on EFL to the exclusion of L2 learning in multilingual contexts. This study aims to explore selfconcept in these contexts and the dialectical role of motivation in creating and drawing on extended learning opportunities available in the multilingual L2 context.

From this review of the literature and the research gap concerning advanced learners in multilingual contexts, the following questions arise:

(1) What attitudes toward Catalan, as an L2 present in the learning context, are displayed by learners at the advanced level?

(2) What motivates L2 learners to persist in their studies of the L2 to advanced levels, according to Self-Determination Theory and the L2 Motivational Self System?

(3) What are the relationships between L2 learners' contact with the L2, learner attitudes, and types of learner motivations?

(4) What are the significant relationships between these constructs and background factors including age, gender, employment status, level of education, length of residence, region of origin, and study center?

\section{Methodology}

\section{Instrument}

The questionnaire used in this study consisted of four sections: background information, contact, attitudes, and motivations. It was developed by the first author drawing primarily on questionnaires used in previous studies (Bernadó et al., 2008; Huguet \& Janés, 2008). To formulate a quantitative measure of contact, participants indicated with whom, how often, 
and in which settings they use the target language outside of class. Information about the presence of the L2 in different networks (use with people including family, friends, and colleagues, five items) was contrasted with frequency of use (one item) and context of use (one item). The attitudes section of the questionnaire (10 yes/no items), published by Huguet and Janés (2008), featured statements related to the aesthetics and importance of Catalan.

Finally, the questionnaire asked learners about their motivation to learn Catalan (40 items on a five-point Likert scale). This section represents the core of the questionnaire and largely reflects the instrument used in Bernadó et al. (2008) supplemented by a review of the literature (Gardner, 1996; Noels et al., 2000; Noels, 2001b). The items encompass the seven orientations cited by Self-Determination Theory, divided into intrinsic and extrinsic factors (from Noels et al., 2000; Noels, 2001b). The intrinsic motivations are the pursuit of knowledge (I like learning languages), sense of accomplishment (I want to speak Catalan fluently), and aesthetic stimulation (I like speaking Catalan). The extrinsic motivations include identified regulation, where the activity is linked to a desired goal (I want to help my children with their schoolwork); introjected regulation, where the learner seeks to alleviate external pressure (Ifeel uncomfortable not knowing how to speak Catalan); external regulation dictated by obligation (My work requires me to learn Catalan); and integrated regulation, the most self-determined motivation (I want to relate better to people here). An eighth scale was added to encompass learning context factors that motivate learners (I have friends and/or family who normally speak Catalan).

\section{Participants}

Both native and non-native speakers attend advanced classes at the CPNL in Barcelona, Spain; the current investigation focuses on the responses of the non-Catalan participants $(N=$ 90). Advanced students in this study are defined as those studying at level C (Common 
European Framework of Reference for Languages). Skills at this level include communicative competence in standard communication as well as flexible and effective communication in formal and informal social situations (CPNL, 2012). Other information about the participants and their use of Catalan is summarized in Table 1.

INSERT TABLE 1 HERE: Learner demographics

\section{Procedure}

Data were collected in November 2011 in thirteen morning, afternoon, and evening sessions in seven Barcelona CPNL study centers encompassing several neighborhoods. The questionnaire, lasting 15 minutes, was administered in written form to entire classes of learners who were invited to complete it on a voluntary basis at the end of the session. The language of the questionnaire was Catalan, as all level $\mathrm{C}$ students were assumed to have advanced proficiency in that language.

\section{Analysis}

Frequencies and descriptive statistics were calculated for all background variables, contact variables, attitudinal scores, and motivational scales. The variable used in measuring learner contact with Catalan was a composite measure based on reported social network use (six points maximum based on three networks [family, friends, and colleagues] and intensity, $1=$ Catalan present, $2=$ Catalan dominant); the frequency scale $(1$ to 5 where $1=$ never and $5=$ daily); and the number of contexts of use (at home, with media, in public, during cultural activities, and at work or school; five points maximum). These measures were weighted by multiplying by 5,10 , and 4 respectively to calculate scores out of 100 , where frequency of use was assumed to be the most telling measure and thus received the greatest consideration. For example, one participant reported using Catalan with friends and colleagues (two 
networks, each Catalan-dominant $=4$ points) on a daily basis ( 5 points) and in three contexts: with media, in public, and at work or school (3 points). This participant's composite measure is thus $4 \times 5$ (weight $)+5 \times 10$ (weight $)+3 \times 4$ (weight $)=82 / 100$ points

The analysis of the attitudinal judgments of Catalan consisted of assigning a point value to each of the 10 statements ( +1 for positive response, -1 for a negative response) and summing. Negatively-worded items were recoded, resulting in a possible range of attitudinal scores from -10 (all negative responses) to +10 (all positive responses).

Analysis of the section on motivation was initially based on eight multi-item scales, representing the categories of intrinsic (three scales, or 13 items) and extrinsic (five scales, or 27 items) motivations from Self-Determination Theory, mentioned above. Each scale contained between three and seven items (see Appendix A). Principal component analysis (PCA), a data reduction technique through which the 40 motivational items were explored and grouped into components based on the similarity of participant responses, revealed four components (after a Varimax rotation) which accounted for 53\% of variance. In subsequent analyses, the four components were used in lieu of the eight Self-Determination Theory motivational scales. Both the attitudinal measure and the motivation components were then correlated with each other and with the composite contact measure. To explore significant differences in mean scores for contact and attitude based on independent background variables, one-way analysis of variance (ANOVA) and $t$-tests were run. For the same purpose, a multivariate analysis of variance (MANOVA) was performed for motivational components, using Wilks' Lambda to determine significance. 


\section{Results}

\section{Contact}

In general, advanced learners of Catalan were found here to use the language in few of the networks cited (with family, friends, or colleagues; $M=1.54 / 6, S D=1.04$ ), but mentioned frequent use outside of class: $60 \%$ reported daily use, $25 \%$ weekly use or several times a week. Additionally, learners used Catalan in three out of five contexts, including with media, in public, and at work or school. These responses were weighted and combined according to the aforementioned formula into the composite score for each participant, where higher scores indicate more L2 contact. The average composite contact score was 60.30/100 (SD = 19.43).

\section{Attitude}

In the present study, participants' attitudes ranged from -6 to 10 , with a rather high average of $7.42(S D=2.8)$. Thirty percent of participants responded positively to all normative statements concerning Catalan use and scored 10/10, and an additional 35\% scored 8 or 9. Thus, a majority of participants weighted the high average, displaying favorable attitudes toward Catalan.

\section{Motivation}

Reviewing the descriptive statistics for motivational items in the questionnaire reveals certain patterns. In 21 of 40 items, more than half of participants strongly agreed with the statements describing their language learning motivations (the highest level of the five-point Likert scale). This is reflected in the skewness values for each motivational scale. Rather than indicating abnormality, the high frequency of positive responses reflects the underlying nature of motivational scales. 
The items that loaded on each of the four motivational components are listed in the PCA chart (see Appendix A) and summarized here in Table 2.

INSERT TABLE 2 HERE: Principal Component Analysis

A total of 12 items loaded on Component 1, 8 from the Intrinsic scales ( 2 for Stimulation, 5 for Knowledge [all items], and 1 for Accomplishment) and 4 from the Extrinsic scales (1 for Social Reinforcement and 3 for Integrated Regulation). Component 1 therefore encompasses intrinsic motivation in general and two of the most self-determined extrinsic scales. This reflects the clear self-concept based on intrinsic motivations found by Noels (2001b) and highlights the gray area on the intrinsic-extrinsic continuum, where the theoretical frameworks presented in the literature review blend and support various explanations. The items that fall under Component 1 reflect theory on the learner's Ideal L2 self as a knowledgeable person (item 3), a participant in cultural events and customs (item 7), and a personally satisfied, interested, open, and principled language learner (remaining items). These positive descriptors characterize the ideal attributes learners strive to attain, and because the high values garnered by Component 1 align with the ideals of the L2 Motivational Self System (Dörnyei, 2009), this component is labeled the Ideal L2 Self.

The items loading on the next component mostly address negative scenarios to be avoided, rather than ideals to be pursued. A total of 13 items loaded on Component 2, 3 from the Intrinsic grouping (Accomplishment) and 10 from the Extrinsic grouping ( 3 from Integrated Regulation, 2 from Identified Regulation, 4 from Introjected Regulation, and 1 from External Regulation). While this may seem like a diverse mix, the underlying theoretical concept relates to the learner's sense of what she ought to be: a confident, fluent 
speaker without nervousness or embarrassment (items 25, 16, 39, 24, 26, 36, 31) who can understand the language (item 32) and settle in Catalonia (items 4, 27, 33, 34, 37). Nine of these items begin with the phrase I want..., differentiating it from other components and demonstrating that learners can be keenly concerned with their self-representation as advanced Catalan students in Catalan society. This component reflects the bidirectional influence of contact and motivation in multilingual contexts: learners in this instance respond to pressure to speak Catalan well and are thus motivated to become highly proficient. Given the theoretical similarity between the images conveyed by these items and the obligations of the L2 Motivational Self System (Dörnyei, 2009), this component is labeled the Ought-to L2 Self.

The influence of learning context on motivation is seen most clearly in the next component. A total of 9 items loaded on Component 3, 2 from the Intrinsic grouping (1 for Stimulation and 1 for Accomplishment) and 7 from the Extrinsic grouping (4 from Social Reinforcement, 1 from Integrated Regulation, and 2 from External Regulation). All items relate to Catalan culture, lifestyle, people, and literature specific to the context where the language is being learned. This component is therefore labeled L2 Context.

Finally, a total of 6 items loaded on Component 4, all extrinsic (3 from Identified Regulation and 3 from External Regulation) and all relating to work, work prospects, or studies. This component is a perfect insight into the least self-determined motives that bring learners to the classroom. Although it stands fourth in explanatory power (8\% of total variance), it is exceptionally theoretically cohesive and is labeled Professional Use.

These four motivational components, each composed of six to thirteen items, were retained for the following MANOVA analysis. Standardized average scores (based on the five-point Likert Scale) and standard deviations are presented in Table 3. 
INSERT TABLE 3 HERE: Standardized component score means

\section{Relationships among contact, attitude, and motivation}

Measures of contact, attitude, and motivation components were correlated in pairs using Pearson product-moment correlations. The strength of the correlations is presented in Table 4 and reveals three significant relationships. First, contact and attitude share a medium-size correlation, as do attitude and Components 1: Ideal L2 Self and 3: L2 Context. Although the three constructs do not jointly correlate in any way, attitude explains nearly $9 \%$ of the variance in the participants' L2 contact and slightly more of the variance in two of the four motivational components.

INSERT TABLE 4 HERE: Pearson product-moment correlations among dependent variables

\section{Relationships between contact, attitude, and motivation and background factors}

To measure the significant relationships between, on the one hand, contact, attitude, and motivation, and on the other hand, the seven independent background variables (age, gender, employment status, level of education, length of residence, region of origin, and study center), a one-way ANOVA was used (except gender, where a $t$-test was required). Then, to compare motivational components to the background variables, a MANOVA was employed.

The ANOVA and $t$-tests used to distinguish between these groups failed to find any significant differences for attitude or contact based on these background factors. This finding may be attributed to the lack of discriminating power in the attitudinal measure, where $65 \%$ of participants scored 8 or above (out of 10). The yes/no format likely detracted from exploring nuances in learners' attitudes toward Catalan.

To prepare the data for a one-way, between-groups MANOVA, variables were checked for sample size, normality, and outliers, resulting in a sample size of 86 participants. 
In this population, the one variable to significantly impact results was region of origin $(F(12$, 209) $=2.31, p=.009 ;$ Wilks' Lambda $=.719 ;$ partial eta squared $=.104)$. When the results per component were considered separately against a Bonferroni adjusted alpha level of .013, the only difference to reach statistical significance was Component 4: Professional Use $(F(3,82)$ $=4.68, p=.005$; partial eta squared $=.146$ ). Thus, the region of origin accounts for $14.6 \%$ of the variance in Professional Use motivation. An inspection of the mean scores revealed that non-Spanish Europeans were less motivated by the professional use of Catalan $(M=.693, S D$ $=.043)$ than Spaniards $(M=.839, S D=.019)$, Latin Americans $(M=.876, S D=.026)$ or others $(M=.792, S D=.046)$.

\section{Discussion}

In essence, this study has investigated advanced learners of Catalan in an effort to explore aspects of learners' self-concept in multilingual contexts. Most research in this area features EFL learners, beginning learners or schoolchildren, and the present work has begun to fill the gap in the literature concerning advanced learners in L2 contexts. It is important to note that the learners documented here, as many adult language learners, are enrolled in a nonobligatory setting, and the results support the positive measures that can be expected of a selfselecting population. Learners with negative attitudes, little L2 contact, and low motivation are simply not present in the population of this study, representing a separate but worthy area of investigation (cf. Newcombe \& Newcombe, 2001). Returning to the knowledge gap concerning advanced learners in multilingual contexts, we now address each research question (RQ) in turn.

This investigation has shown in regards to RQ1 (attitudes) that learners studying level C Catalan have an overwhelmingly positive evaluation of the language. A strong majority $(65 \%)$ agreed with at least 8 of the 10 value statements including I enjoy hearing people 
speak Catalan, and I live in a place where Catalan is spoken, so I should know and use it. This finding reflects the link found by Coupland et al. (2005) between advanced language proficiency and positive attitudes toward target language use and the significant and direct correlation between proficiency and attitude confirmed by Lasagabaster (2005) in research in the multilingual Basque context. Taken together, these findings suggest that the disposition of advanced learners toward the L2 becomes increasingly positive over the course of study, integrating the L2 into learner self-concept.

RQ2 addresses learner motivations, which PCA attributed to four components explaining a total of $53.2 \%$ of variance. This measure indicates that advanced learners are highly motivated, averaging $3.93 / 5$ for motivation overall. Considering the variance explained per component, we find a weight of $17.1 \%$ for Component 1: Ideal L2 Self, $16.1 \%$ for 2: Ought-to L2 Self, 11.6\% for 3: L2 Context, and 8.4\% for 4: Professional Use. The weight of learners' possible selves is evident, as their future self-guides motivate them to reduce the discrepancy between their current and future selves (Dörnyei, 2009; Higgins, 1987). Also present is the effect of environmental factors which the second language context provides, highlighting that learners in multilingual contexts routinely encounter opportunities to put their imagined selves into practice.

These motivational components reflect those found by Bernadó et al. (2008) for beginning learners of Catalan, suggesting that motivation does not dynamically interact with proficiency level in multilingual contexts. However, further research focused on this context is needed to confirm the consistency of motivation over time and explore the nature of motivational dynamics at different timescales. Focusing specifically on parallels between beginning and advanced learners, we see that analogous questionnaire items characterize the primary motivational factor for both beginning learners (general intrinsic motivation) and 
advanced learners in this study. Specifically, eight items motivating beginning learners were also rated highly by advanced learners of Catalan in Component 1: Ideal L2 Self. Additionally, another eight items (linguistic anxiety and integrative motivation) rated similarly for advanced learners in Component 2: Ought-to L2 Self. These items reflect the negative motivations that push learners to fluency, and the similar responses of beginning and advanced learners of Catalan point to the continued importance of Ought-to L2 self imagery. Finally, L2 use for work and studies continues to be a motivation for advanced learners in Component 4: Professional Use. Consistency of these motivational components over the course of study may further distinguish the multilingual L2 context from FL contexts currently at the center of research on the L2 Motivational Self System.

Regarding RQ3 (relationships among the constructs), three significantly positive correlations were revealed. The first positive correlation emerged between attitude and contact, again reflecting the positive evolution of dispositions toward L2 use through L2 contact in situ (Coupland et al., 2005; Lasagabaster, 2005). Another positive correlation was found between attitude and the Ideal L2 Self (supported by Gardner, 2001 and Noels, 2001b, in addition to Dörnyei, 2003, 2005). The third positive correlation linked attitude and $L 2$ Context, explaining 9.4\% of variance and confirming the importance of Gardner's notion of integrativeness for L2 study in multilingual contexts. It should again be noted that all three constructs obtained high frequencies and, although not discriminatory in this sample, are considered mutually reinforcing. The complementary nature of these constructs in this multilingual context may be attributable to the advanced proficiency level of the participants, since in Lasagabaster's (2005) study, degree of competence and sociolinguistic context are shown to powerfully mediate language attitudes toward second and foreign languages.

Finally, RQ4 explored significant relationships among the constructs and background factors. Only one statistically significant difference was found to distinguish participants: 
learners of European origin outside of Spain showed less Professional Use motivation than other groups. No significant relationship was found between attitude, contact, and region of origin, contrary to the findings of Huguet and Janés (2008) for immigrant learners but similar to those of Bernaus et al. (2007), where region of origin was found to have little significant effect. We might attribute these contradictory results to participant demographics, since participants in the current study voluntarily pursue advanced proficiency and are likely to validate that effort. These studies, while addressing some background factors, do not directly address proficiency level except where year level (Bernaus et al., 2007) serves as a possible proxy and reveals decreasing attitude and motivation levels as level increases. The same trend has been documented in FL settings (Chambers, 1999). This discrepancy emphasizes the need for additional research linking contact, attitude and motivation to proficiency level through mediating background variables and the context of language learning.

The present study contributes to filling this research gap and indicating directions for further investigation. The findings demonstrate that advanced learners exhibit favorable attitudes, intrinsic ideals (attributed here to the Ideal L2 self-concept), and extrinsic pressures (Ought-to L2 self) predominantly unaffected by background variables. Additionally, the L2 context was not incidental but instead proved essential to learning motivation, explaining $11.6 \%$ of variance. These findings, combined with those for beginning learners (Bernadó et al., 2008), point to the weight of context in language learning motivation and underline the research imperative to account for it. This sample demonstrated a uniquely motivated profile, where possible selves and the significant L2 context intertwine and reinforce each other.

Some limitations are present in the study. The participant population is small $(N=$ 90), as the number of non-Catalans studying at level $\mathrm{C}$ is markedly inferior to the number of Catalans $(N=181$ in our total sample). Because few non-Catalans persist to high levels of 
proficiency (of enrolled students in all levels, this population outnumbers Catalan natives 5 to 1; CPNL, 2012) future research should study the motivations of non-Catalans who begin language classes but do not attain level C. Secondly, questionnaire research features selfreported and often anonymous information. Interviews, when possible, would provide richer data on this complex phenomenon, particularly focusing on a dynamic, emergent, and situated view of motivation (Ushioda, 2009). Longitudinal data would also aid in documenting the changing nature of motivation as learners progress from beginning to advanced levels. Finally, homogeneous scores for the three constructs in question reveal not only high frequencies and positive measures but might also reflect a lack of discriminatory power.

\section{Conclusion}

The results of this study elicit aspects of the L2 Motivational Self System overlooked by current L2 self-concept research, which has focused primarily on EFL learners. As MacIntyre, Mackinnon, and Clément write, '[T]he possible selves and integrative motivation perspectives are not mutually exclusive, and are instead complementary concepts that map much of the same phenomenological territory' (2009, p. 43). Self-Determination Theory also shares this common ground: intrinsic and internalized extrinsic motivation questionnaire items formed a cohesive whole reflective of learners' Ideal L2 selves (Component 1); conversely, introjected norms and other extrinsic motivations shaped Component 2, a representation of learner's Ought-to L2 selves. Opening this theoretical common ground leaves space for L2 learners in multilingual contexts.

Specifically, advanced Catalan learners in this study have reaffirmed the importance of integrativeness through their L2 contact, positive attitudes and Ideal L2 self concepts related to settling in Catalonia. This finding leads us to ask: How are Ideal and Ought-to L2 
selves manifested when the diverse L2 community is not abroad but at hand, and the learner seeks to participate in cultural events and public life? In multilingual contexts such as Catalonia, an integrative orientation remains relevant for beginning and advanced learners alike, and L2 self-concept must account for it. Additional studies in multilingual contexts are necessary to elucidate the nature of this expansion of the L2 Motivational Self System.

The findings of this study are unique in that they provide an insight into the motivational self-concept of advanced L2 learners in multilingual contexts. In addition to the development of theory, investigating what draws these learners to pursue advanced proficiency bears greatly on continued linguistic diversity. This study on motivation reflects the incentives learners feel to study Catalan and the incorporation of language study into selfconcept, a timely and poignant topic for learners in multilingual contexts. 
Appendix A: Principal Components Analysis

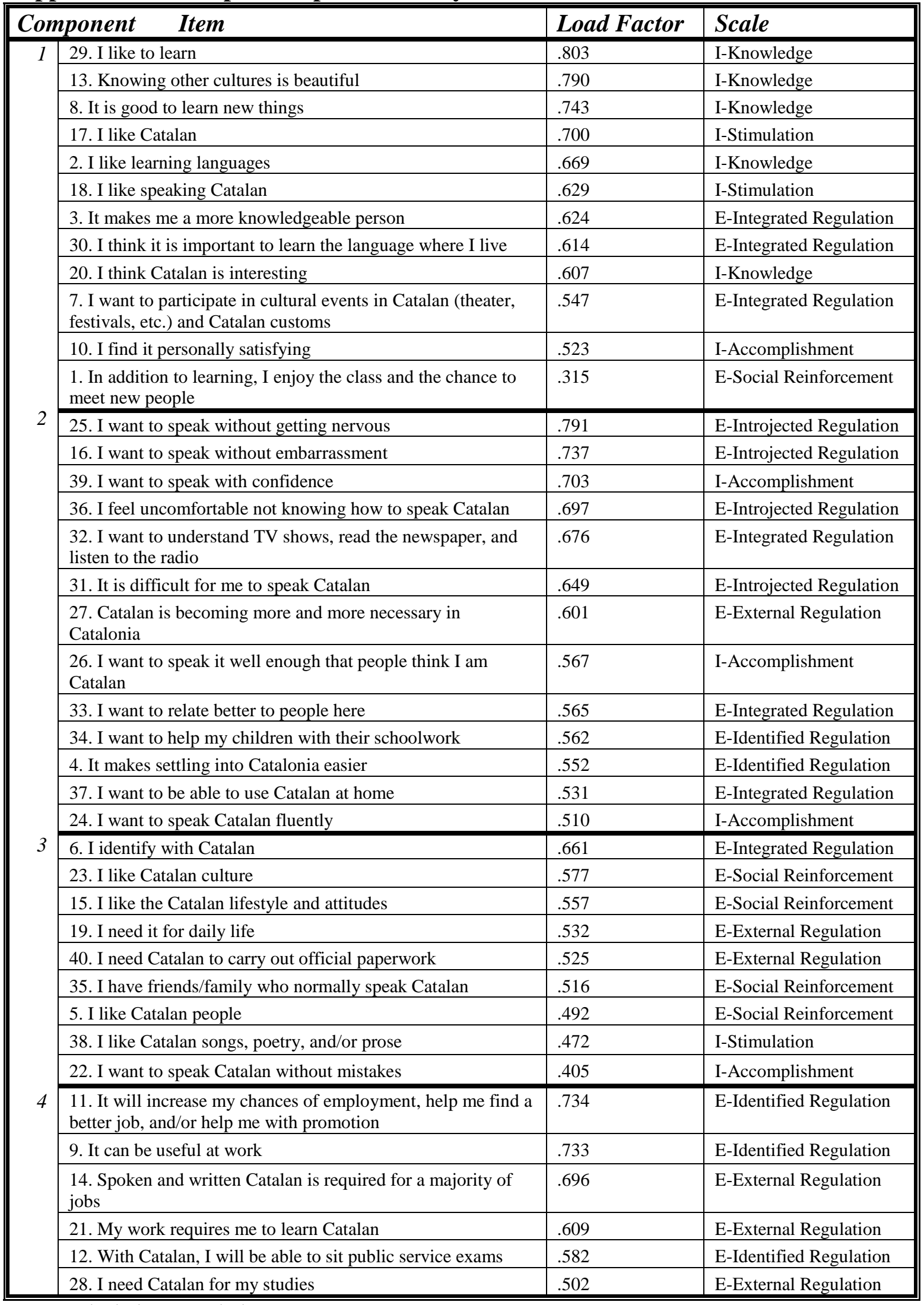

Note: $\mathrm{I}=$ intrinsic, $\mathrm{E}=$ extrinsic 


\section{Appendix B: ANOVA and $t$-test results}

\begin{tabular}{|c|c|c|c|c|}
\hline $\begin{array}{c}\text { Background } \\
\text { Factor }\end{array}$ & Construct & $F$ & $d f^{\neq}$ & $p$ \\
\hline \multirow[t]{2}{*}{ Study center } & Contact & .013 & 2,86 & .987 \\
\hline & Attitude & 1.540 & 5,79 & .187 \\
\hline \multirow[t]{2}{*}{ Age } & Contact & .453 & 7,82 & .865 \\
\hline & Attitude & .681 & 2,81 & .509 \\
\hline \multirow{2}{*}{$\begin{array}{l}\text { Length of } \\
\text { residence }\end{array}$} & Contact & .044 & 2,73 & .957 \\
\hline & Attitude & .274 & 2,44 & .762 \\
\hline \multirow[t]{2}{*}{ Employment } & Contact & 1.677 & 5,81 & .149 \\
\hline & Attitude & 1.399 & 3,78 & .249 \\
\hline \multirow[t]{2}{*}{ Education } & Contact & .815 & 5,79 & .543 \\
\hline & Attitude & 1.356 & 4,75 & .257 \\
\hline \multirow[t]{2}{*}{ Region of origin } & Contact & .577 & 6,83 & .747 \\
\hline & Attitude & .236 & 3,81 & .871 \\
\hline
\end{tabular}

₹ Reported as between groups, within groups

* Sig. at $p \leq 0.05$.

\begin{tabular}{||l|l|c|c|c||}
\hline Construct & \multicolumn{1}{|c|}{ Gender } & $\boldsymbol{M},($ SD) & $\boldsymbol{t}$ & $\boldsymbol{p}$ \\
\hline Contact & Male & $57.52(21.28)$ & -.888 & .377 \\
& Female & $61.49(18.64)$ & & \\
\cline { 2 - 5 } Attitude & Male & $6.85(2.60)$ & -1.882 & .063 \\
& Female & $7.88(2.22)$ & & \\
\hline
\end{tabular}

\footnotetext{
* Sig. at $p \leq 0.05$.
} 
Appendix C: MANOVA results

\begin{tabular}{|c|c|c|c|c|}
\hline $\begin{array}{c}\text { Background } \\
\text { Factor }\end{array}$ & Component & $F$ & $d f$ & $n^{2}$ \\
\hline \multirow[t]{4}{*}{ Study center } & 1 & .697 & 5 & .042 \\
\hline & 2 & .552 & 5 & .034 \\
\hline & 3 & .346 & 5 & .021 \\
\hline & 4 & 1.985 & 5 & .110 \\
\hline \multirow[t]{4}{*}{ Age } & 1 & .670 & 2 & .016 \\
\hline & 2 & .424 & 2 & .010 \\
\hline & 3 & .337 & 2 & .008 \\
\hline & 4 & .398 & 2 & .010 \\
\hline \multirow{4}{*}{$\begin{array}{l}\text { Length of } \\
\text { residence }\end{array}$} & 1 & .369 & 2 & .011 \\
\hline & 2 & 1.515 & 2 & .042 \\
\hline & 3 & .095 & 2 & .003 \\
\hline & 4 & 1.145 & 2 & .032 \\
\hline \multirow[t]{4}{*}{ Gender } & 1 & 2.678 & 1 & .031 \\
\hline & 2 & 2.149 & 1 & .025 \\
\hline & 3 & 1.501 & 1 & .018 \\
\hline & 4 & .002 & 1 & .000 \\
\hline \multirow[t]{4}{*}{ Employment } & 1 & .819 & 3 & .030 \\
\hline & 2 & 1.030 & 3 & .038 \\
\hline & 3 & 1.392 & 3 & .050 \\
\hline & 4 & $2.894 *$ & 3 & .099 \\
\hline \multirow[t]{4}{*}{ Education } & 1 & .062 & 4 & .037 \\
\hline & 2 & .036 & 4 & .011 \\
\hline & 3 & .084 & 4 & .039 \\
\hline & 4 & .014 & 4 & .009 \\
\hline \multirow[t]{4}{*}{ Region of origin } & 1 & $2.835^{*}$ & 3 & .094 \\
\hline & 2 & 1.718 & 3 & .059 \\
\hline & 3 & .743 & 3 & .026 \\
\hline & 4 & $4.682 * *$ & 3 & .146 \\
\hline
\end{tabular}

* Sig. at $p \leq 0.05$.

** Sig. at $p \leq 0.013$. 


\section{References}

Bernadó, C., Comajoan, L., \& Bastons, N. (2008). Anàlisi Factorial dels Motius d'Aprenentatge del Català com a Llengua segona i Relació amb el Nivel, el Temps d'Estada, l'Edat i el Centre d'estudi dels Alumnes [Factorial analysis of motives for learning Catalan as a second language and relation to learners' level, length of stay, age, and study center]. Catalan Review, 22, 71-89.

Bernaus, M., Masgoret, A.-M., Gardner, R., \& Reyes, E. (2004). Motivation and Attitudes Towards Learning Languages in Multicultural Classrooms. International Journal of Multilingualism, 1(2), 75-89.

Bernaus, M., Moore, E., \& Cordeiro Azevedo, A. (2007). Affective Factors Influencing Plurilingual Students' Acquisition of Catalan in a Catalan-Spanish Bilingual Context. The Modern Language Journal, 91(2), 235-246.

Chambers, G. (1999). Motivating Language Learners. Clevedon: Multilingual Matters.

Coupland, N., Bishop, H., Williams, A., Evans, B., \& Garrett, P. (2005). Affiliation, Engagement, Language use and Vitality: Secondary School Students' Subjective Orientations to Welsh and Welshness. International Journal of Bilingual Education and Bilingualism, 8(1), 1-24.

Cots, J., \& Nussbaum, L. (2008). Communicative Competence and Institutional Affiliation: Interactional Processes of Identity Construction by Immigrant Students in Catalonia. International Journal of Multilingualism, 5(1), 17-40.

CPNL (Consorci per a la Normalització Lingüística). (2012). Memòria 2012. http://www.cpnl.cat/arxius/consadm/93/memoria2012_digital.pdf

Daming, X., Xiaomei, W., \& Wei, L. (2008). Social Network Analysis. In L. Wei \& M. Moyer (Eds.), The Blackwell Guide to Research Methods in Bilingualism and Multilingualism (pp. 263-274). Hoboken, NJ: Wiley-Blackwell.

Deci, E., \& Ryan, R. (1985). Intrinsic Motivation and Self-Determination in Human Behaviour. New York: Plenum.

Dörnyei, Z. (2003). Attitudes, Orientations, and Motivations in Language Learning: Advances in Theory, Research, and Applications. Malden, MA: Blackwell.

Dörnyei, Z. (2005). The Psychology of the Second Language Learner: Individual Differences in Second Language Acquisition. Mahwah, NJ: Lawrence Erlbaum Associates. 
Dörnyei, Z. (2009). The L2 Motivational Self System. In Z. Dörnyei \& E. Ushioda (Eds.), Motivation, Language Identity, and the L2 Self (pp. 9-42). Bristol: Multilingual Matters.

Dörnyei, Z., \& Ushioda, E. (Eds.). (2009). Motivation, Language Identity, and the L2 Self. Bristol: Multilingual Matters.

Freed, B., Dewey, D., Segalowitz, N., \& Halter, R. (2004). The Language Contact Profile. Studies in Second Language Acquisition, 26, 349-356.

Gardner, R. (1996). Motivation and Second Language Acquisition: Perspectives. Journal of the CAAL, 18(2), 19-42.

Gardner, R. (2000). Correlation, Causation, Motivation and Second Language Acquisition. Canadian Psychology, 41, 1-24.

Gardner, R. (2001). Integrative Motivation and Second Language Acquisition. In Z. Dörnyei \& R. Schmidt (Eds.), Motivation and Second Language Acquisition (pp. 1-19). Honolulu, HI: U of Hawai'i Second Language Teaching and Curriculum Centre.

Gardner, R. (2010). Motivation and Second Language Acquisition: The Socio-Educational Model. New York: Peter Lang.

Goldberg, E., \& Noels, K. (2006). Motivation, Ethnic Identity, and Post-Secondary Education Language Choices of Graduates of Intensive French Language Programs. The Canadian Modern Language Review, 62(3), 423-447.

Gore, S. (2002). The Catalan Language and Immigrants from Outside the European Union. International Journal of Iberian Studies, 15(2), 91-102.

Higgins, E. (1987). Self-Discrepancy: A Theory Relating Self and Affect. Psychological Review, 94, 319-340.

Huguet, A., \& Janés, J. (2008). Mother Tongue as a Determining Variable in Language Attitudes. The Case of Immigrant Latin American Students in Spain. Language and Intercultural Communication, 8(4), 246-260.

Huguet, A., \& Llurda, E. (2001). Language Attitudes of School Children in Two Catalan/Spanish Bilingual Communities. International Journal of Bilingual Education and Bilingualism, 4(4), 267-282.

Lasagabaster, D. (2005). Attitudes towards Basque, Spanish and English: An analysis of the most influential variables. Journal of Multilingual and Multicultural Development, 26(4), 296-316.

MacIntyre, P., Mackinnon, S., \& Clément, R. (2009). The Baby, the Bathwater, and the Future of Language Learning Motivation Research. In Z. Dörnyei \& E. Ushioda 
(Eds.), Motivation, Language Identity, and the L2 Self (pp. 43-65). Bristol:

Multilingual Matters.

Masgoret, A.-M., \& Gardner, R. (2003). Attitudes, Motivation, and Second Language

Learning: A Meta-Analysis of Studies Conducted by Gardner and Associates.

Language Learning, 53(1), 123-163.

Milroy, L. (1980). Language and Social Networks. Oxford: Basil Blackwell.

Milroy, L. (2000). Social Network Analysis and Language Change: Introduction. European Journal of English Studies, 4(3), 217-223.

Moraga, J., \& Ferrer-i-Carbonell, A. (2008). Immigration in Catalonia. Institut d'Análisis Económic (IAE-CSIC).

http://www.iae.csic.es/specialMaterial/a8263153727sp5537.pdf

Newcombe, L., \& Newcombe, R. (2001). Adult Language Learning: The Effect of Background, Motivation and Practice on Perseverance. International Journal of Bilingual Education and Bilingualism, 4(5), 332-354.

Noels, K. (2001a). Learning Spanish as a Second Language: Learners' Orientations and Perceptions of Their Teachers' Communication Style. Language Learning, 51, $107-$ 144.

Noels, K. (2001b). New orientations in language learning motivation: Towards a model of intrinsic, extrinsic, and integrative orientations and motivation. In Z. Dörnyei \& R. Schmidt (Eds.), Motivation and Second Language Acquisition (pp. 43-68). Honolulu, HI: U of Hawai'i Second Language Teaching and Curriculum Centre.

Noels, K., Pelletier, L., Clément, R., \& Vallerand, R. (2000). Why Are You Learning a Second Language? Motivational Orientations and Self-Determination Theory. Language Learning, 50, 57-85.

Raschka, C., Wei, L., \& Lee, S. (2002). Bilingual Development and Social Networks of British-Born Chinese Children. International Journal of the Sociology of Language, $153,9-25$.

SPSS (20.0 for Windows) [Computer software]. SPSS Inc.

Trenchs-Parera, M., \& Newman, M. (2009). Diversity of Language Ideologies in SpanishSpeaking Youth of Different Origins in Catalonia. Journal of Multilingual and Multicultural Development, 30(6), 509-524. 
Ushioda, E. (2009). A Person-in-Context Relational View of Emergent Motivation, Self and Identity. In Z. Dörnyei \& E. Ushioda (Eds.), Motivation, Language Identity, and the L2 Self (pp. 215-228). Bristol: Multilingual Matters.

Ushioda, E. (2011). Language Learning Motivation, Self and Identity: Current Theoretical Perspectives. Computer Assisted Language Learning, 24(3), 199-210.

Wiklund, I. (2002). Social Networks from a Sociolinguistic Perspective: The Relationship between Characteristics of the Social Networks of Bilingual Adolescents and Their Language Proficiency. International Journal of the Sociology of Language, 153, 5392. 
Table 1: Learner demographics $(N=90)$

\begin{tabular}{|c|c|c|c|c|c|c|c|}
\hline \multicolumn{2}{|l|}{ Category } & $N$ & $\%$ & \multicolumn{2}{|l|}{ Category } & $N$ & $\%$ \\
\hline \multirow[t]{2}{*}{ Gender } & Male & 27 & 30 & \multirow[t]{3}{*}{ Length of Study } & One course & 5 & 6 \\
\hline & Female & 63 & 70 & & $<1$ year & 11 & 12 \\
\hline \multirow[t]{4}{*}{ Geographic Origin } & Spain & 48 & 53 & & $>1$ year & 70 & 78 \\
\hline & Rest of Europe & 9 & 10 & \multirow[t]{3}{*}{ Class Time } & Morning & 27 & 30 \\
\hline & Latin America & 25 & 28 & & Afternoon & 6 & 7 \\
\hline & Other & 8 & 9 & & Evening & 57 & 63 \\
\hline \multirow[t]{3}{*}{ L1 } & Spanish & 66 & 73 & \multirow{3}{*}{$\begin{array}{l}\text { Catalan Social } \\
\text { Network Use }\end{array}$} & With family & 1 & 1 \\
\hline & Spanish + other & 6 & 7 & & With friends & 48 & 53 \\
\hline & Other & 17 & 19 & & With colleagues & 64 & 71 \\
\hline \multirow[t]{4}{*}{ Employment } & Full-time & 34 & 38 & \multirow{5}{*}{$\begin{array}{l}\text { Frequency of } \\
\text { Use }\end{array}$} & Never & 2 & 2 \\
\hline & Part-time & 12 & 13 & & Occasionally & 12 & 13 \\
\hline & Unemployed & 29 & 32 & & Weekly & 12 & 13 \\
\hline & Other & 12 & 13 & & Several times/week & 12 & 13 \\
\hline \multirow[t]{5}{*}{ Education } & Secondary & 14 & 15 & & Daily & 52 & 58 \\
\hline & University & 38 & 42 & & & & \\
\hline & Master & 23 & 26 & & & & \\
\hline & Doctorate & 5 & 6 & & & & \\
\hline & Other & 5 & 6 & & & & \\
\hline & Range (years) & \multicolumn{2}{|c|}{ Mean } & & & & \\
\hline Age & $19-60$ & \multicolumn{2}{|c|}{39.3} & & & & \\
\hline Length of Stay & $2-50$ & \multicolumn{2}{|c|}{11.2} & & & & \\
\hline
\end{tabular}


Table 2: Principal Component Analysis

\begin{tabular}{|r|c|c|c|c||}
\hline \multicolumn{1}{|c|}{ Component } & \# Items & Eigenvalues & \% Variance Explained & $\begin{array}{c}\text { Cronbach Alpha } \\
\text { reliability }\end{array}$ \\
\hline 1: Ideal L2 Self & 12 & 12.6 & 17.1 & .91 \\
\hline 2: Ought-to L2 Self & 13 & 4.0 & 16.1 & .91 \\
\hline 3: L2 Context & 9 & 2.7 & 11.6 & .80 \\
\hline 4: Professional Use & 6 & 1.9 & 8.4 & .73 \\
\hline
\end{tabular}


Table 3: Standardized component score means

\begin{tabular}{||l|l|l||}
\hline \hline Component & $\begin{array}{l}\text { Average Score } \\
\text { (standardized) }\end{array}$ & SD \\
\hline 1: Ideal L2 Self & 4.25 & .70 \\
\hline 2: Ought-to L2 Self & 3.67 & 1.00 \\
\hline 3: L2 Context & 3.68 & .80 \\
\hline 4: Professional Use & 4.1 & .65 \\
\hline
\end{tabular}


Table 4: Pearson product-moment correlations among dependent variables

\begin{tabular}{||c|c|c|c|c|c|c||}
\hline \multirow{2}{*}{ Contact } & \multirow{2}{*}{ Attitude } & \multicolumn{4}{|c|}{ Motivation Components } \\
\cline { 4 - 7 } & & & 1: Ideal L2 Self & $\begin{array}{l}\text { 2: Ought-to L2 } \\
\text { Self }\end{array}$ & $\begin{array}{l}3: \text { L2 } \\
\text { Context }\end{array}$ & 4: Professional Use \\
\hline Contact & 1.0 & $\begin{array}{c}.459^{*} \\
(24.5)\end{array}$ & $-.117(1.3)$ & $-.100(1.0)$ & $-.164(2.7)$ & $.026(.1)$ \\
\hline Attitude & $\begin{array}{c}.459 * \\
(24.5)\end{array}$ & 1.0 & $.302 *(9.1)$ & $-.153(2.3)$ & $.370 *(9.4)$ & $-.069(.5)$ \\
\hline
\end{tabular}

Numbers are $r$ values; * significant value; shared variance is communicated in parentheses; $p<0.01$ 